\title{
Thermal Performance Evaluation of
} Walls with Gas Filled Panel Insulation

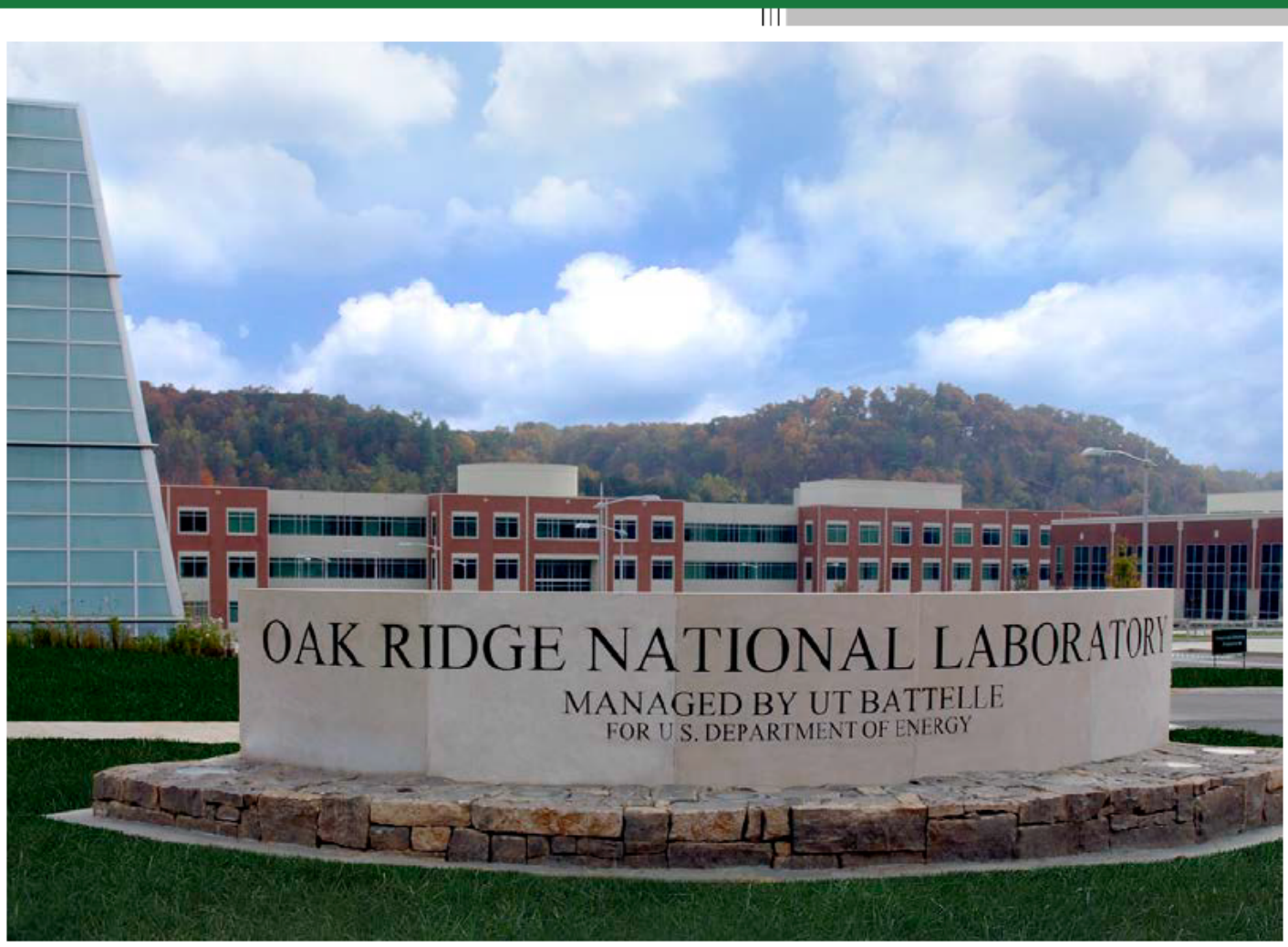

Som Shrestha, Ph.D. Andre Desjarlais Jerald Atchley

October 2014 


\section{DOCUMENT AVAILABILITY}

Reports produced after January 1, 1996, are generally available free via US Department of Energy (DOE) SciTech Connect.

Website http://www.osti.gov/scitech/

Reports produced before January 1, 1996, may be purchased by members of the public from the following source:

National Technical Information Service

5285 Port Royal Road

Springfield, VA 22161

Telephone 703-605-6000 (1-800-553-6847)

TDD 703-487-4639

Fax 703-605-6900

E-mail info@ntis.gov

Website http://www.ntis.gov/help/ordermethods.aspx

Reports are available to DOE employees, DOE contractors, Energy Technology Data Exchange representatives, and International Nuclear Information System representatives from the following source:

Office of Scientific and Technical Information

PO Box 62

Oak Ridge, TN 37831

Telephone 865-576-8401

Fax 865-576-5728

E-mail reports@osti.gov

Website http://www.osti.gov/contact.html

This report was prepared as an account of work sponsored by an agency of the United States Government. Neither the United States Government nor any agency thereof, nor any of their employees, makes any warranty, express or implied, or assumes any legal liability or responsibility for the accuracy, completeness, or usefulness of any information, apparatus, product, or process disclosed, or represents that its use would not infringe privately owned rights. Reference herein to any specific commercial product, process, or service by trade name, trademark, manufacturer, or otherwise, does not necessarily constitute or imply its endorsement, recommendation, or favoring by the United States Government or any agency thereof. The views and opinions of authors expressed herein do not necessarily state or reflect those of the United States Government or any agency thereof. 
Energy and Transportation Science Division

\title{
Thermal Performance Evaluation of Walls with Gas Filled Panel Insulation
}

\author{
Som Shrestha, Ph.D. \\ Andre Desjarlais \\ Jerald Atchley
}

Date Published: October, 2014

\author{
Prepared by \\ OAK RIDGE NATIONAL LABORATORY \\ Oak Ridge, Tennessee 37831-6283 \\ managed by \\ UT-BATTELLE, LLC \\ for the \\ US DEPARTMENT OF ENERGY \\ under contract DE-AC05-00OR22725
}





\section{INTRODUCTION}

Gas filled insulation panels ${ }^{1}$ (GFP) are very light weight and compact (when uninflated) advanced insulation products. GFPs consist of multiple layers of thin, low emittance (low-e) metalized aluminum. When expanded, the internal, low-e aluminum layers form a honeycomb structure. These baffled polymer chambers are enveloped by a sealed barrier and filled with either air or a low-conductivity gas. The sealed exterior aluminum foil barrier films provide thermal resistance, flammability protection, and properties to contain air or a low conductivity inert gas. This product was initially developed with a grant from the U.S. Department of Energy.

The unexpanded product is nearly flat for easy storage and transport. Therefore, transportation volume and weight of the GFP to fill unit volume of wall cavity is much smaller compared to that of other conventional insulation products. This feature makes this product appealing to use at Army Contingency Basing, when transportation cost is significant compared to the cost of materials. The objective of this study is to evaluate thermal performance of walls, similar to those used at typical Barracks Hut (B-Hut) hard shelters, when GFPs are used in the wall cavities. Oak Ridge National Laboratory (ORNL) tested performance of the wall in the rotatable guarded hotbox (RGHB) according to the ASTM C 1363 standard test method.

\section{BACKGROUND AND TEST WALL DETAILS}

A team consisting of ORNL researchers and U. S Army Engineer Research and Development Center (ERDC) - Construction Engineering Research Laboratory (CERL) researchers identified GFPs as potential insulation system to be used in B-Huts. The ORNL objective of this project is to assist ERDC-CERL researchers to evaluate the thermal performance of wall assembly consisting of GFP using RGHB. Yarbrough et al. (2007) evaluated thermal performance of gasfilled panels with reflective surfaces installed in an attic using ORNL large scale climate simulator (LSCS). The study found that the total contribution of the GFP layer installed above fiberglass batt insulation was 5 to $6 \mathrm{~h} \bullet \mathrm{ft}^{2} \cdot{ }^{\circ} \mathrm{F} / \mathrm{Btu}$ for winter conditions and about $6 \mathrm{~h} \bullet \mathrm{ft}^{2}{ }^{\circ} \circ \mathrm{F} / \mathrm{Btu}$ for summer conditions. No other test result was available in published literature that showed performance of GFP insulated walls.

The construction of test wall resembles that of typical B-Hut wall, except that GFPs were used in cavities of test wall; whereas no insulation is used in typical B-Hut wall cavities. The test wall was constructed of nominal $2 \times 4$ lumber studs 16 -in. on center (O. C.) with 0.5-in. plywood on both sides of the wall. Figure 1 shows the test wall being assembled for RGHB test.

Exposed side of the materials used on exterior of the GFPs had low-e coating. Thermal emittance of the polymer with and without low-e metalized aluminum coating were measured using Devices \& Services emissometer model AE, which was operated in accordance with ASTM C 1371. Table 1 shows the measured emittances.

The GFPs were inflated with compressed air with a pressure regulator set at 7 psig. Some of the GFPs were bulged during inflation. Severely bulged GFPs were not used in this test. One GFP

1 http://www.fifoil.com/products/advanced-solutions-systems-reflective-insulation/gfp-insulation 
was punctured by a splinter while installing the GFP on test wall. The punctured GFP was replaced. Honeycomb structure of the GFP was visually inspected (Figure 2) by cutting one panel. Thickness of the inflated GFP was about 1.5-in., thus two layers of GFPs fills the cavities between $2 \times 4$ studs.

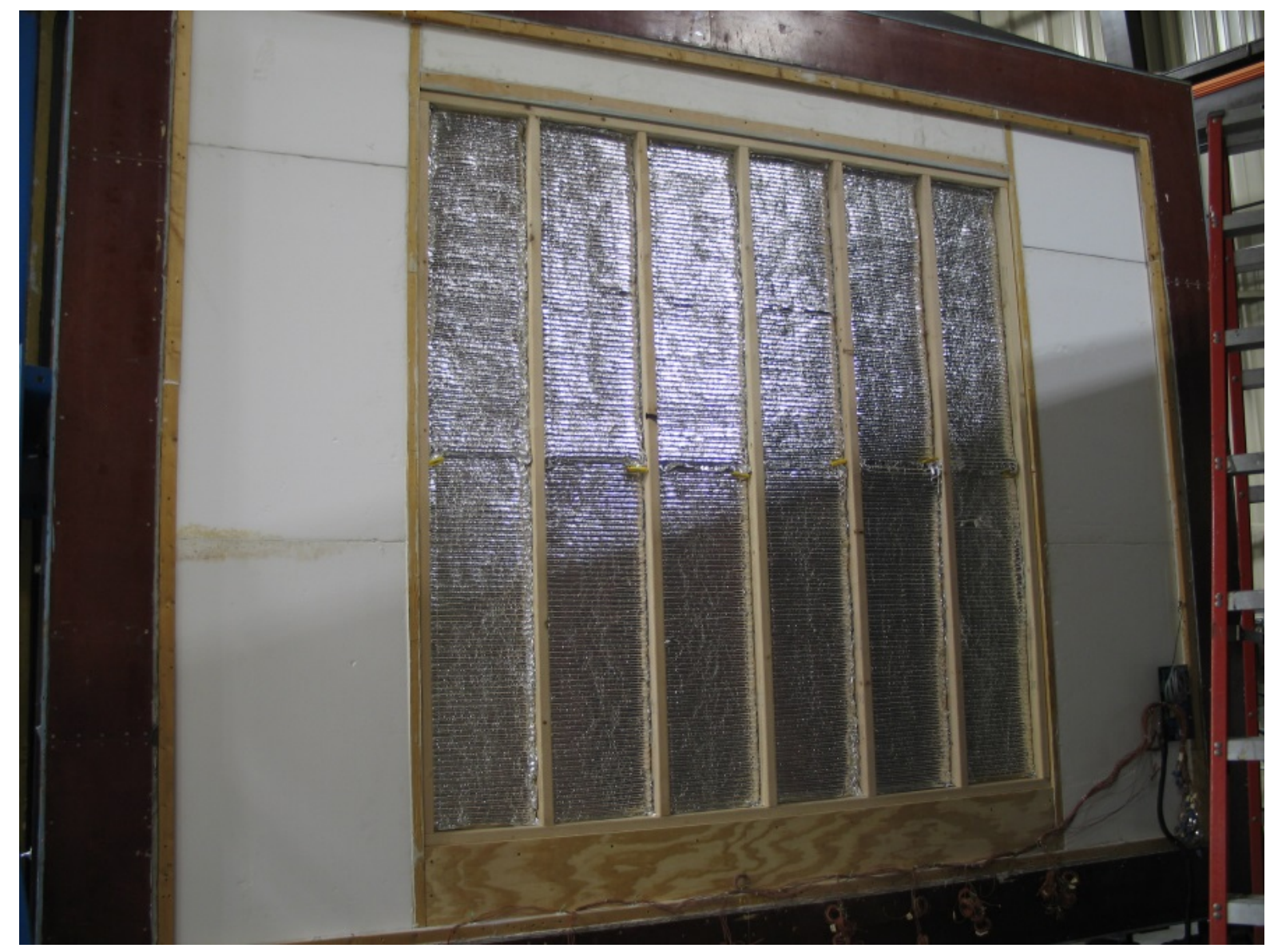

Figure 1. Test wall with GFPs in the cavity.

Table 1 Thermal emittance of the GFP material

\begin{tabular}{|c|c|c|}
\hline \multirow{2}{*}{ Sample } & \multicolumn{2}{|c|}{ Thermal Emittance } \\
\cline { 2 - 3 } & $\begin{array}{c}\text { Surface with } \\
\text { low-e coating }\end{array}$ & $\begin{array}{c}\text { Surface } \\
\text { without low-e } \\
\text { coating }\end{array}$ \\
\hline \hline 1 & 0.08 & 0.65 \\
\hline 2 & 0.10 & 0.66 \\
\hline 3 & 0.08 & 0.68 \\
\hline 4 & 0.07 & 0.61 \\
\hline Average & $\underline{0.08}$ & $\underline{0.65}$ \\
\hline
\end{tabular}




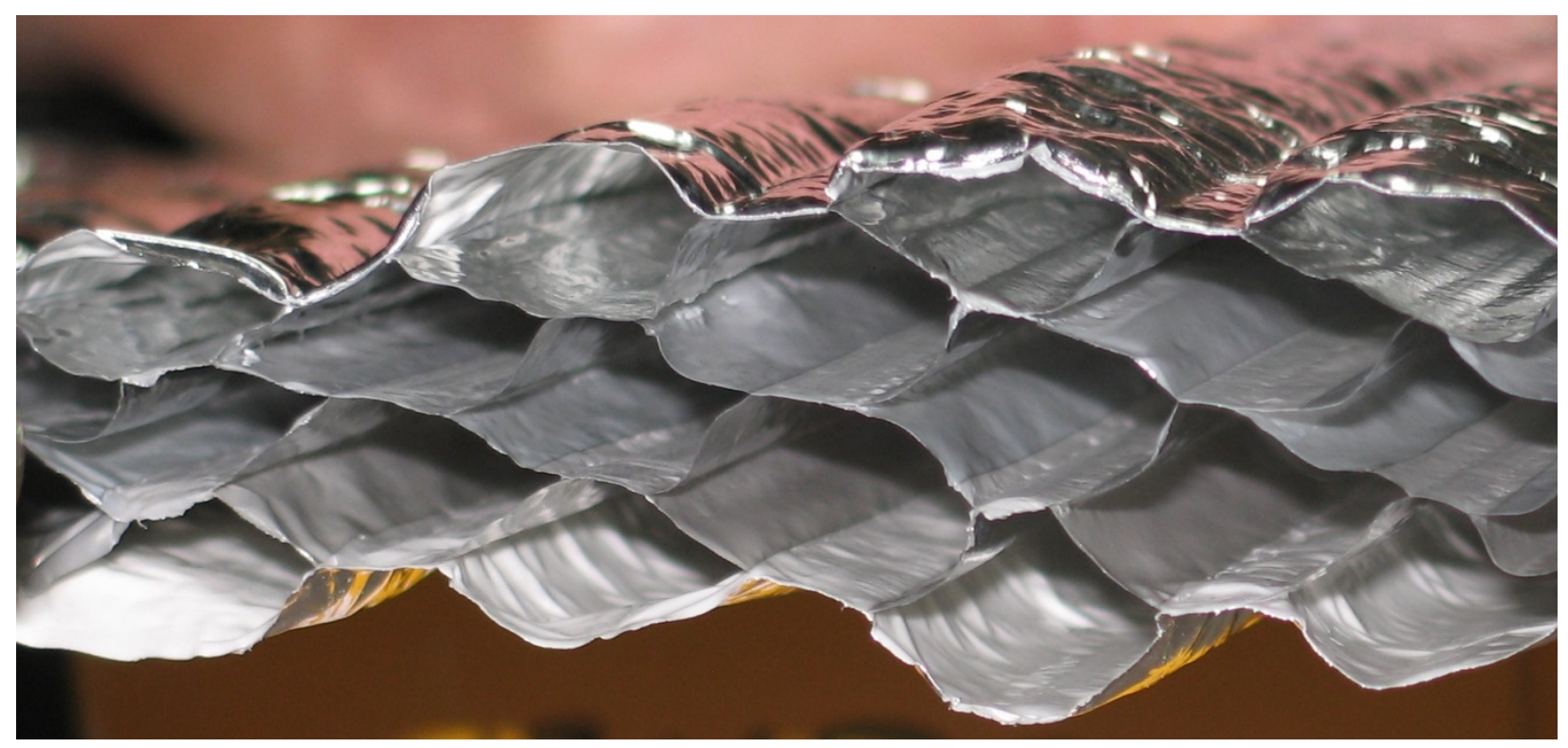

Figure 2. Honeycomb structure of the GFP.

\section{TEST APPARATUS AND INSTRUMENTATION}

ORNL operates and maintains a guarded hot-box that is used to measure the effective thermal resistance (R-Value) and thermal transmittance (U-Factor) of full size wall and window assemblies. The box operates under the requirements of ASTM C 1363. Test assemblies are installed in a specimen frame mounted on a moveable dolly. The specimen frame has an aperture of $13-\mathrm{ft}$. long by $10-\mathrm{ft}$. high. The specimen frame/test assembly is inserted between two "clam-shell" chambers of identical cross-section. The placement of the test wall assembly between the chambers allows the chamber temperatures to be independently controlled, thus creating a temperature difference across the specimen. The chambers are designated as the climate (cold) and metering/guard (hot) chambers. A photograph of the RGHB is shown in Figure 3 and Figure 4 shows a typical wall specimen installed in the test frame. The central $8-\mathrm{ft} \times 8-\mathrm{ft}$ wall section, which aligns with the metering chamber boundary, is used for the actual test. 


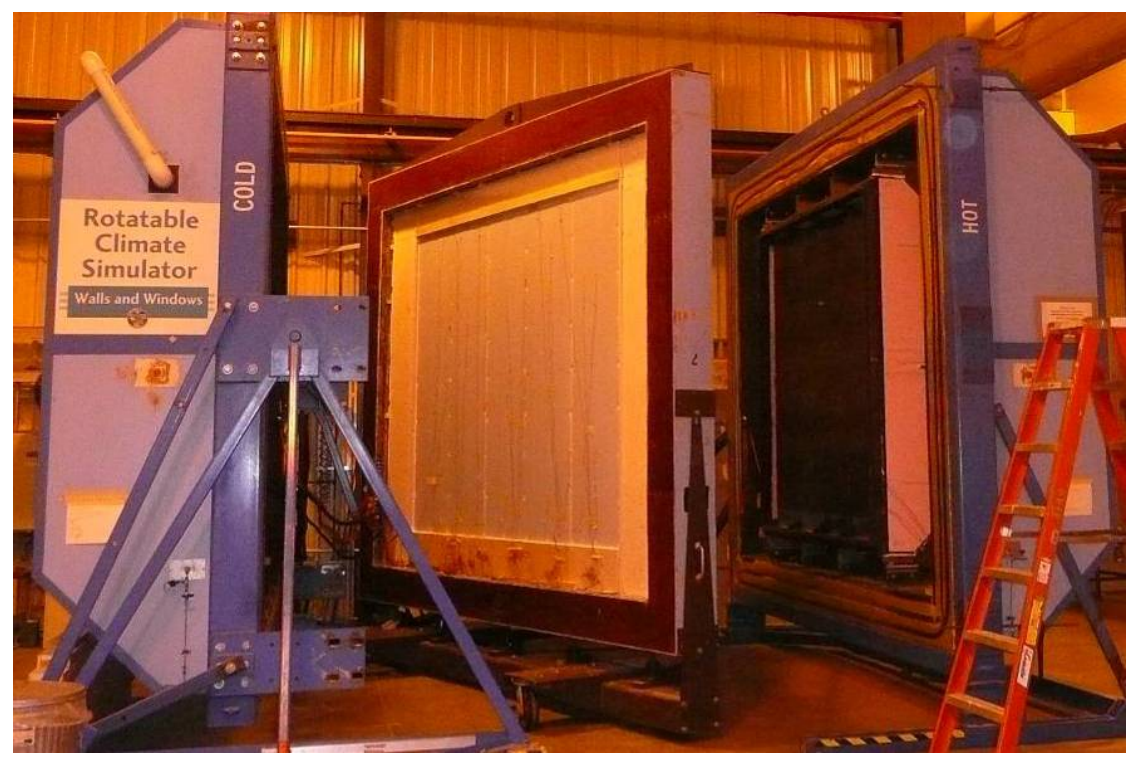

Figure 3. ORNL Rotatable Guarded Hot Box.

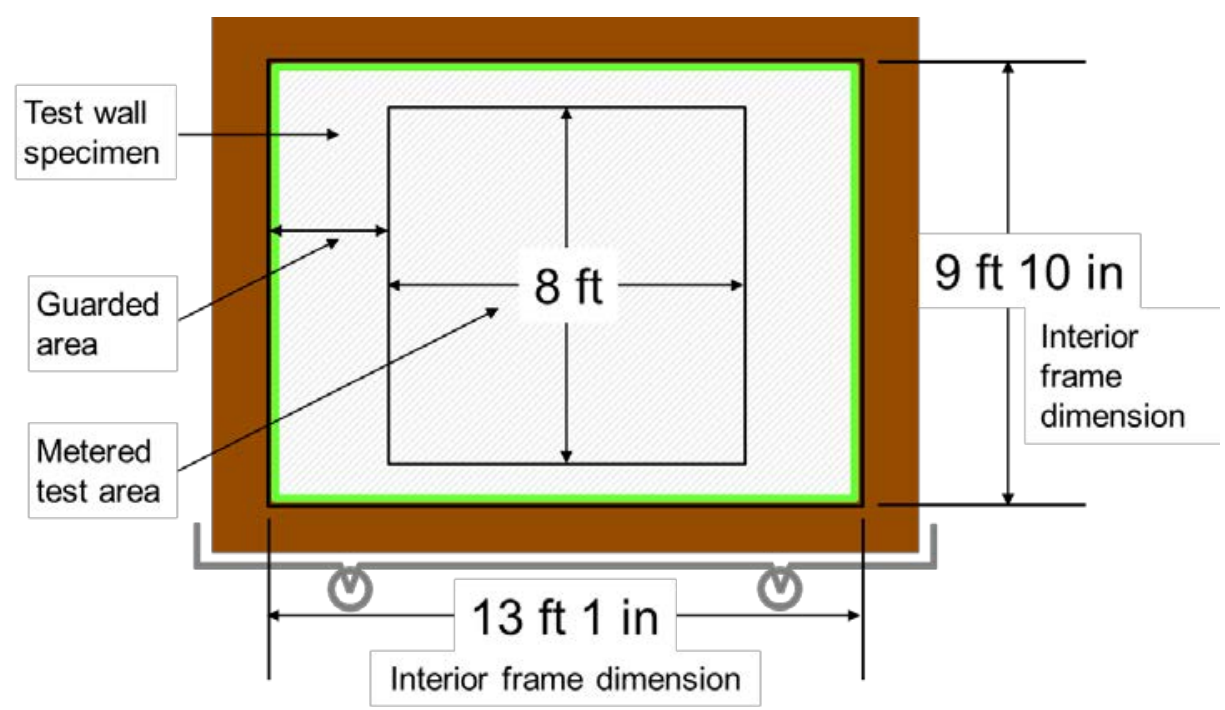

Figure 4. Schematic of a typical test wall within the hot-box test frame.

The climate chamber (cold side) is equipped with blowers and an air-conditioning system capable of producing stable environmental conditions to the extremes of $10^{\circ} \mathrm{F}$ and $15 \mathrm{mph}$ wind velocities. Five centrifugal squirrel cage air blowers, installed behind a baffle, are used to circulate the air through the airspace between the baffle and test specimen assembly. Five hot-wire anemometers, located in the center of the air stream produced by each of the five squirrel cage blowers, continuously measure the wind speed across the baffle surface. Temperature measurement of the baffle and air is accomplished by a series of thermocouples distributed evenly over the baffle surface. The thermocouples are distributed such that the average air and surface temperature of the center 8-ft. x 8-ft. area, which is utilized for the actual 
test, facing the test specimen can also be obtained. A relative humidity probe is located inside the climate chamber to monitor the relative humidity. The baffle surface facing the test specimen is covered with a black coating with an emittance of 0.9 .

The hot side consists of two similarly shaped chambers; a guard chamber surrounding the smaller metering chamber. The metering chamber has heaters and fans capable of producing stable environmental conditions to the extremes of $140^{\circ} \mathrm{F}$ and $2.0 \mathrm{mph}$ wind velocities. The metering chamber is approximately 8 -ft. square by 1.3 -ft. deep and is suspended from the inside of the guard chamber by spring loaded brackets, which constantly push the open face of the metering chamber up against the warm side of the test specimen. The guard chamber and the climate chamber are then sealed against each side of the test frame with separate inflatable gaskets. The walls of the metering chamber are constructed with 3-in. thick aged extruded polystyrene foam having an approximate thermal resistance, $R_{m b}, 15 \mathrm{~h} \cdot \mathrm{ft}^{2} \bullet{ }^{\circ} \mathrm{F} / \mathrm{Btu}$ at $75^{\circ} \mathrm{F}$. A baffle is mounted inside the metering box, 6-in. from the exposed edge of the gasket. Behind the baffle, an array of eight fans and four electric resistance heaters force air upward between the baffle, through the resistance heaters, and then downward through the airspace between the baffle and test assembly. A relative humidity probe is mounted on the baffle surface inside the metering box. The average baffle air and surface temperature of the meter baffle is measured by equally spaced thermocouples attached to the surface and in the air space 3-in. away from the surface. There are four warm side hot-wire anemometer velocity probes on the baffle surface and an absolute pressure tap located on the baffle surface near the geometric center of the baffle.

A 92 junction (46 pair) differential thermopile is applied on the interior and exterior walls of the metering chamber to sense the temperature imbalance across the metering chamber wall. Each thermopile junction is mounted in the center of one of the 48 equal areas into which the metering chamber is divided. The interior thermopile junction is mounted directly opposite the corresponding exterior junction. Additional arrays of temperature sensors are affixed to both the meter-side and climate-side surfaces of the foam panel surrounding the test specimen in the area covered by the guard chamber.

The guard box has four heaters and six fans that heat and circulate the air in the guard space surrounding the metering box. The heaters are controlled by a PID controller that senses the surface temperature difference across the metering box walls measured by the metering box wall thermopile. The guard chamber also contains a relative humidity probe.

Three differential pressure transducers are installed in the RGHB. Two of the transducers, P1 and P2, measure the pressure difference across the test assembly. The third transducer, P3, monitors the pressure difference between the metering and guard chambers.

During operation, the temperatures of the climate and metering chambers are set at the desired level. Separate programmable D.C. power supplies in conjunction with a temperature controller are used to energize and control the metering chamber heaters and fans. The power to the fans is adjusted to set the desired wind speed in the airspace between the baffle and the test wall assembly. Anemometers are used to monitor this wind speed. The output of the differential thermopile controls the guard chamber heaters through a differential temperature controller. By 
this technique, the temperature difference across the metering box walls is minimized, thereby essentially eliminating the heat flow between the metering and guard chambers.

All temperature measurements are performed using Type T-type copper/constantan thermocouples calibrated to the special limits of error specified in ASTM E 230, "TemperatureElectromotive Force (EMF) Tables for Standardized Thermocouples". All sensors inside the RGHB are connected to a data acquisition system capable of measuring either thermocouple output or raw voltage signals. The modules used to measure thermocouples have an internal electronic reference junction to accurately calculate the temperature from the raw thermocouple output. Once started, the data acquisition modules automatically collect data at 30 second intervals for all sensors except those used for measuring energy input into the metering chamber, which are on 12 second intervals. All the instrumentation and control equipment used in the RGHB are annually calibrated against NIST traceable standards at ORNL or they are returned to the instrument manufacturer for calibration.

The heat flow generated by the metering chamber heaters is calculated from the voltage and current measurements taken from a precision shunt resistor as well as a watt-transducer. The energy dissipated by the metering chamber fans is metered with a precision resistor network. Once steady-state conditions have been achieved, the test period is continued until at least five successive data acquisition runs of periods equal to the time constant of the RGHB are obtained. The test is considered complete when each datum obtained for each measured variable differs from its mean by no more than the uncertainty of that variable. In addition, the data must not vary monotonically with time.

Over the years, ORNL has performed many characterization tests to ensure that the RGHB meets the specifications in the annex of ASTM C 1363. The standard requires the determination of a system time constant as well as flanking losses and null offset. Although the results from these time constant and flanking loss tests are not presented here, it should be noted that test data have been compiled and analyzed to verify that the RGHB meets the requirements of ASTM C 1363.

\section{CALCULATION METHODOLGY}

The meter and climate side average surface temperatures are calculated in an appropriate areaweighted manner. The surface area of the wall used for the test was 64- $\mathrm{ft}^{2}$. The percentage of the total wall surface area that each individual wall component comprised was determined. The average temperatures were then computed by area-weighing the average cavity, stud, and track surface temperatures.

The energy exchange rate from the metering box to the guard chamber, $Q_{m b}$ is calculated by equation 1.

$$
Q_{m b}=\frac{A_{m b} \cdot \Delta T_{m b}}{R_{m b}}
$$

where $Q_{m b}=$ heat flow rate through metering box walls, Btu/h 

$A_{m b}=\quad$ surface area of the metering box, $100.08 \mathrm{ft}^{2}$
$\Delta T_{m b}=$ temperature difference between the guard side and meter side of the metering box walls, ${ }^{\circ} \mathrm{F}$
$R_{m b}=\quad$ thermal resistance of the metering box walls, $15 \mathrm{~h} \bullet \mathrm{ft}^{2} \bullet{ }^{\circ} \mathrm{F} / \mathrm{Btu}$.

The total energy flow through the wall assembly, $Q_{\text {wall }}$, is calculated from

$$
Q_{\text {wall }}=Q_{h}+Q_{\text {fan }}+Q_{m b}+Q_{v p}
$$

where $Q_{\text {wall }}=$ total energy flow rate through the wall assembly, Btu/h

$Q_{h} \quad=\quad$ energy input to the resistance heaters in the metering chamber, Btu/h

$Q_{f a n}=$ energy input to the fans in the metering chamber, Btu/h

$Q_{v p} \quad=\quad$ energy input to the velocity probes in the metering chamber, Btu/h

The surface-to-surface thermal resistance of the wall assembly, $R_{\text {wall }}$, is calculated from

$$
R_{\text {wall }}=\frac{A_{\text {wall }} \cdot\left(T_{m s}-T_{c s}\right)}{Q_{\text {wall }}}
$$

where $R_{\text {wall }}=$ surface-to-surface thermal resistance of the wall assembly, $\mathrm{h} \cdot \mathrm{ft}^{2} \bullet{ }^{\circ} \mathrm{F} / \mathrm{Btu}$

$A_{\text {wall }}=$ area of wall, $\mathrm{ft}^{2}$

$T_{m s}=$ area weighted average metering-side surface temperature, ${ }^{\circ} \mathrm{F}$

$T_{c s}=$ area weighted average climate-side surface temperature, ${ }^{\circ} \mathrm{F}$

\section{TEST CONDITIONS}

The tests were conducted with three configurations:

1. Two layers of GFPs on cavities between studs

2. One layer of GFP on climate side

3. Without GFPs

Length of GFPs was 4-ft., so two GFPs were used to cover the 8-ft height of the test wall. The motivation for conducting the test with one layer of GFP was to evaluate if only one layer of GFP can be used without compromising the effective R-value significantly. Each configuration was tested at three temperature conditions to evaluate change in R-value as a function of temperature. Following are the test conditions used:

1. Meter side surface temperature $80^{\circ} \mathrm{F}$ and climate side surface temperature $40^{\circ} \mathrm{F}$

2. Meter side surface temperature $100^{\circ} \mathrm{F}$ and climate side surface temperature $60^{\circ} \mathrm{F}$

3. Meter side surface temperature $120^{\circ} \mathrm{F}$ and climate side surface temperature $80^{\circ} \mathrm{F}$

The meter side and climate side surface temperatures were determined by area-weighted averaging of the thermocouples attached to the individual components. On each side of the wall, 32 thermocouples were used to measure surface temperature. 
The perimeter of the test wall and the joints were caulked and taped to prevent air leakage. The data from the final 15 hours after achieving stable temperature and heat flow conditions were used for the analysis.

\section{TEST RESULTS}

Temperatures, heat flows and R-values are presented in Table 1. (A nomenclature list follows the table.) Table 1 also summarizes the calculated surface-to-surface R-values. For visual comparison, Figure 5 shows R-value as a function of temperature for walls with two layers of GFP and one layer of GFP. It is interesting to note that while the R-value of the wall with two layers of GFP decreases sharply(change from $8.662 \mathrm{~h} \cdot \mathrm{ft}^{2} \cdot{ }^{\circ} \mathrm{F} / \mathrm{Btu}$ at $80 / 40^{\circ} \mathrm{F}$ to $7.762 \mathrm{~h} \cdot \mathrm{ft}^{2} \cdot{ }^{\circ} \mathrm{F} / \mathrm{Btu}$ at $120 / 80^{\circ} \mathrm{F}$, resulting $10.4 \%$ decrease in R-value) as the temperature increases, the R-value of the wall with only one layer of GFP remains fairly steady (change from $7.241 \mathrm{~h} \cdot \mathrm{ft}^{2} \bullet{ }^{\circ} \mathrm{F} / \mathrm{Btu}$ at $80 / 40^{\circ} \mathrm{F}$ to $7.183 \mathrm{~h} \cdot \mathrm{ft}^{2}{ }^{\circ} \mathrm{F} / \mathrm{Btu}$ at $120 / 80^{\circ} \mathrm{F}$, resulting only $0.8 \%$ decrease in R-value). At $120^{\circ} \mathrm{F}$ hot side surface temperature and $80^{\circ} \mathrm{F}$ cold side surface temperature, the R-value of the wall with one layer of GFP is only $7.5 \%$ less than that of the wall with two layers of GFP. This phenomenon can be explained with the data available in Section 26 of ASHRAE Handbook of Fundamentals (ASHRAE 2013).

Figure 6 presents the relevant data from Section 26 of ASHRAE 2013; effective R-value of plain air spaces as a function of mean temperature for horizontal heat flow when temperature difference is $10^{\circ} \mathrm{F}$ and effective emittance is 0.05 . Note that while R-value of 0.5 -in. air space decreases as the mean temperature increases, it is just opposite for 1.5-in. air space. Even though the conditions in GFP test are not exactly the same as in ASHRAE 2013, analogy can be made between test data and the ASHRAE 2013 data. The test wall with two layers of GFP contains six layers of approximately 0.5-in. air spaces. Therefore, the R-value decreases as the mean temperature increases. For the test wall with one layer of GFP, the cavity between studs are filled with three layers of approximately 0.5 -in. air spaces and one layer of approximately 1.5 -in. air space. The R-value of 0.5-in. air space decreases and that of 1.5-in. air space increases as the mean temperature increases. Thus, the resulting R-value for the test wall with one layer of GFP remains fairly steady over the range of temperature used in the tests. 
Table 2 Summary test results

\begin{tabular}{|l|r|r|r|r|r|r|r|r|r|}
\hline \multirow{2}{*}{$\begin{array}{l}\text { Wall } \\
\text { Configuration }\end{array}$} & \multicolumn{4}{|c|}{ Two Layers GFP } & \multicolumn{3}{c|}{ One Layer GFP on Climate } & \multicolumn{3}{c|}{ No GFP } \\
\cline { 2 - 10 } & $80 / 40$ & $100 / 60$ & $120 / 80$ & $80 / 40$ & $100 / 60$ & $120 / 80$ & $80 / 40$ & $100 / 60$ & $120 / 80$ \\
\hline \hline M-FAN-PWR & 3.9 & 3.9 & 3.8 & 3.9 & 3.8 & 3.8 & 3.9 & 3.8 & 3.8 \\
\hline M-HTR-PWR & 271.4 & 287.5 & 305.3 & 329.8 & 331.9 & 332.7 & 1132.6 & 1013.2 & 1052.3 \\
\hline M-VEL-PWR & 20.2 & 20.0 & 19.7 & 20.0 & 19.6 & 19.3 & 19.7 & 9.9 & 9.9 \\
\hline$Q_{m b}$ & -0.1 & -0.1 & -0.1 & -0.1 & -0.1 & -0.1 & -0.1 & -0.1 & -0.1 \\
\hline TMP_DC & 295.4 & 311.3 & 328.7 & 353.6 & 355.3 & 355.8 & 1156.0 & 1026.9 & 1065.9 \\
\hline T-DIFF & 40.0 & 40.1 & 39.9 & 40.0 & 39.9 & 40.0 & 40.1 & 40.1 & 39.9 \\
\hline R-value & $\mathbf{8 . 6 6 2}$ & $\mathbf{8 . 2 3 2}$ & $\mathbf{7 . 7 6 2}$ & $\mathbf{7 . 2 4 1}$ & $\mathbf{7 . 1 9 2}$ & $\mathbf{7 . 1 8 3}$ & $\mathbf{2 . 2 1 8}$ & $\mathbf{2 . 5 0 0}$ & $\mathbf{2 . 3 9 6}$ \\
\hline
\end{tabular}

Nomenclature for Table 1:

M-FAN-PWR = Meter fan power, Btu/h

M-HTR-PWR = Meter heater power, Btu/h

M-VEL-PWR = Meter velocity probe power, Btu/h

$Q_{m b} \quad=$ heat flow rate through metering box walls, Btu/h

TMP-DC = Total heat flow rate into meter box, Btu/h

T-DIFF $\quad=$ Average temperature difference across wall surfaces, ${ }^{\circ} \mathrm{F}$

R-value $\quad=$ Surface to surface R-value of the wall, $\mathrm{h} \cdot \mathrm{ft}^{2} \bullet^{\circ} \mathrm{F} / \mathrm{Btu}$

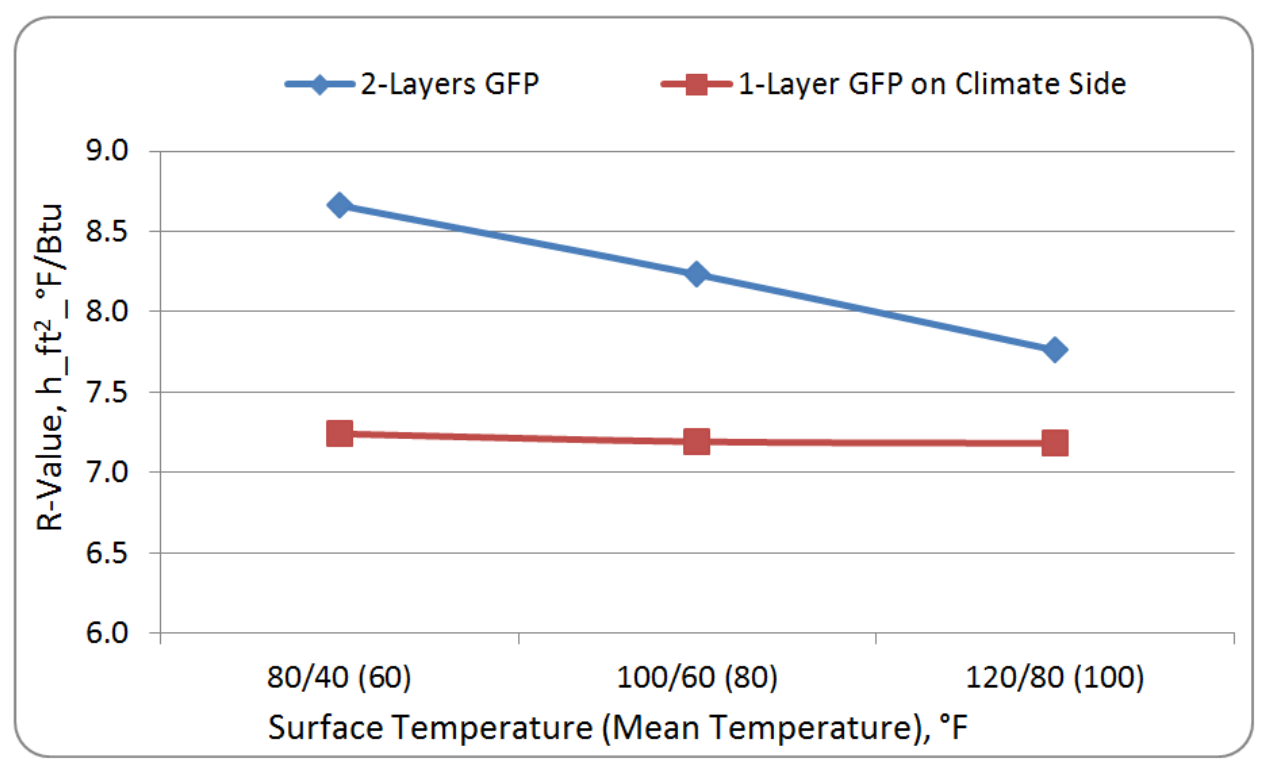

Figure 5. R-value as a function of temperature. 


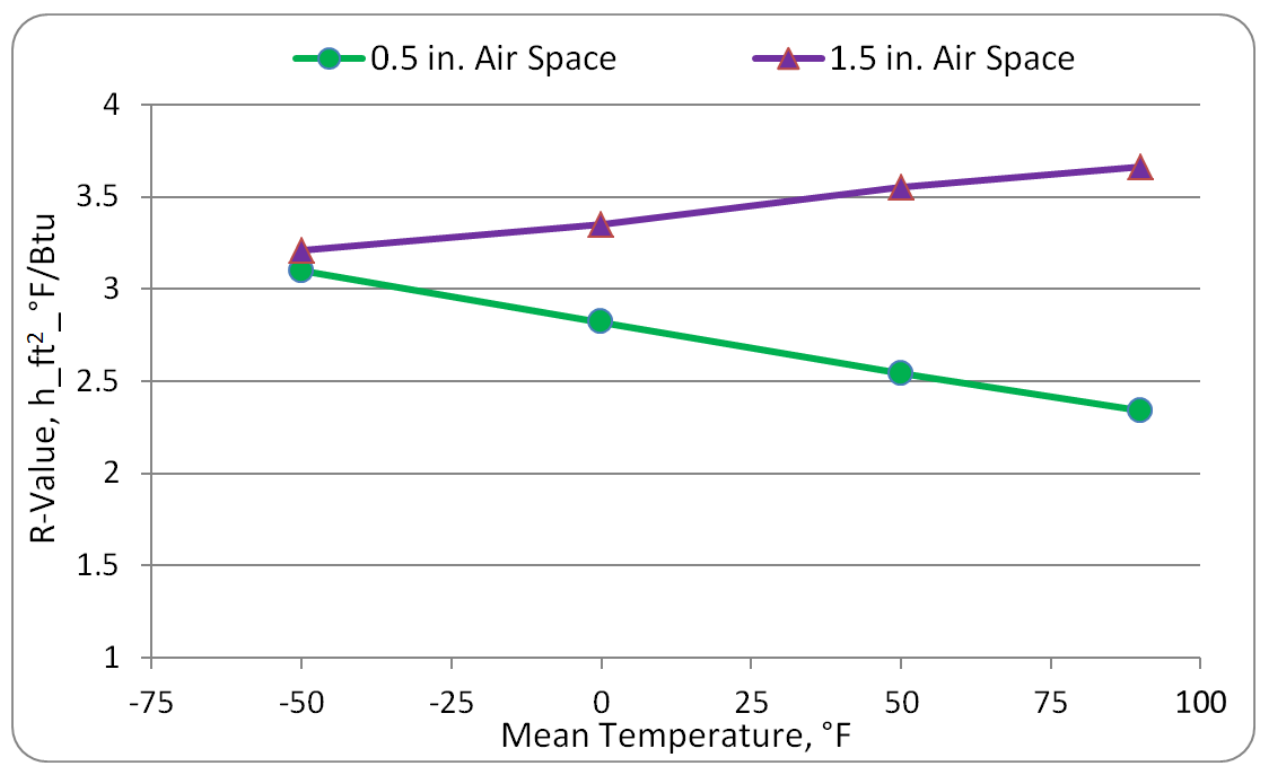

Figure 6. Effective thermal resistance of plane air spaces (ASHRAE 2013).

Figure 7 shows the increase in effective surface-to-surface R-value due to the use of GFPs in wall cavities. While the increase in R-value is significant, several factors (such as cost of materials, transportation, energy, weather conditions, application) would need to be considered to determine whether it is cost effective to use one layer or two layers of GFP in the B-Hut cavity.

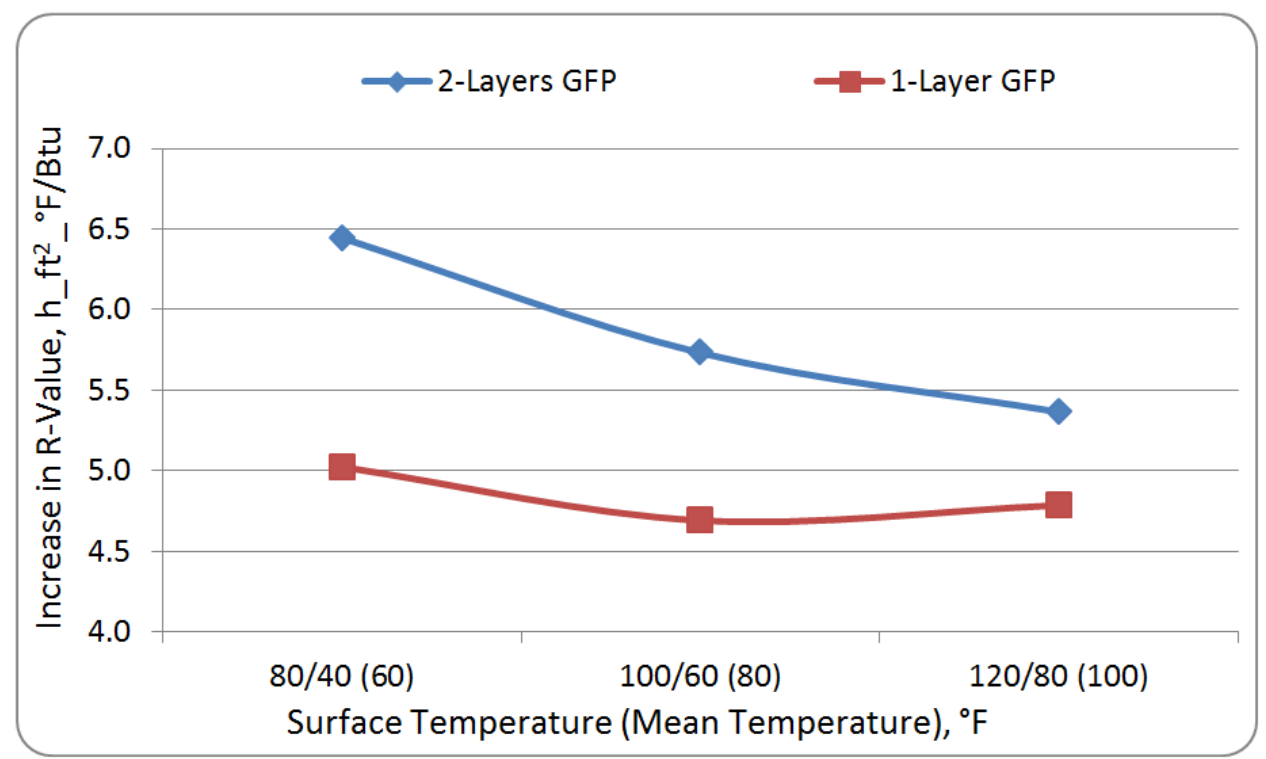

Figure 7. Increase in R-value due to the use of GFPs in wall cavities.

\section{SUMMARY}

In spring of 2014, thermal performance testing of wall assembly with two layers of gas filled insulation panel (GFP), one layer of GFP, and without GFP was conducted in Oak Ridge National Laboratory. The test wall was constructed of nominal 2x4 lumber studs 16-in. on 
center with 0.5-in. plywood on both sides of the wall. The walls were tested in the Rotatable Guarded Hot Box (RGHB) according to the ASTM C 1363 standard test method. The test result show that while the effective surface-to surface thermal resistance (R-value) of the wall with two layers of GFP decreases sharply as the temperature of the GFPs increases, the R-value of the wall with only one layer of GFP remains fairly steady.

For the range of test conditions ( 80,100 , and $120^{\circ} \mathrm{F}$ hot side surface temperature and 40,60 , $80^{\circ} \mathrm{F}$ cold side surface temperature), the R-value range from 8.662 to $7.762 \mathrm{~h} \bullet \mathrm{ft}^{2} \bullet^{\circ} \mathrm{F} / \mathrm{Btu}$ for the wall with two layers of GFP, 7.241 to $7.183 \mathrm{~h}^{\circ} \mathrm{ft}^{2}{ }^{\circ} \mathrm{F} / \mathrm{Btu}$ for the wall with one layer of GFP, and 2.218 to $2.396 \mathrm{~h} \cdot \mathrm{ft}^{2}{ }^{\circ}{ }^{\circ} \mathrm{F} / \mathrm{Btu}$ for the wall without GFP. Thus, the increase in R-value was 6.444 to $5.366 \mathrm{~h} \cdot \mathrm{ft}^{2} \bullet{ }^{\circ} \mathrm{F} / \mathrm{Btu}$ for the wall with two layers of GFP and 5.024 to $4.787 \mathrm{~h} \bullet \mathrm{ft}^{2} \cdot{ }^{\circ} \mathrm{F} / \mathrm{Btu}$ for the wall with one layer of GFP compared to the wall without GFP.

Several factors (such as cost of materials, transportation, energy, weather conditions, application) would need to be considered to determine whether it is cost effective to use one layer or two layers of GFP in the B-Hut cavity. Simulation study is recommended to quantify potential energy savings and associated cost savings potential of GFPs while used in B-Huts.

\section{REFERENCES}

ASTM C 1363-05: Standard Test Method for Thermal Performance of Building Materials and Envelope Assemblies by Means of a Hot-Box Apparatus.

ASHRAE 2013. American Society of Heating, Refrigerating and Air-Conditioning Engineers (ASHRAE) Handbook of Fundamentals 2013

Yarbrough D. W., T. W. Petrie, D. Kinninger, and R. S. Graves. 2007. Thermal Performance of Gas-Filled Panels with Reflective Surfaces Installed in an Attic. 